\title{
CHEMICAL COMPOSITION OF BULK PRECIPITATION AT URBAN AND RURAL AREAS OF KARNATAKA, INDIA.
}

\author{
G.P. Shivashankara, G.P. Munawar, S. Nagendra and B.C. Prasad \\ PES College of Engineering, Mandya, Karnataka state, India \\ Email: gpshivashankara@yahoo.com
}

\begin{abstract}
Bulk precipitation is a mixture of rain (wet +Dry) and dries fallout. As sampled, bulk precipitation is the solution formed when dry fallout is washed into the collecting vessel by rain water. The resulting solution is bulk precipitation. There are 316 samples were collected during the study period, 2005 to 2007 at urban and rural areas. Concentration of major cations $\left(\mathrm{H}^{+}, \mathrm{Ca}^{2+}, \mathrm{Mg}^{2+}, \mathrm{Na}^{+}, \mathrm{K}^{+}\right.$, and $\left.\mathrm{NH}_{4}{ }^{+}\right)$and anions $\left(\mathrm{Cl}^{-}, \mathrm{SO}_{4}{ }^{2}, \mathrm{HCO}_{3}{ }^{-}, \mathrm{NO}_{2}{ }^{-}, \mathrm{NO}_{3}{ }^{-}\right.$and $\left.\mathrm{PO}_{4}{ }^{3}\right)$ were determined and predominant ions were identified. The study showed that the volume weighted mean $\mathrm{pH}$ of bulk precipitation at Hebbal-Bangalore north area was 4.70 in which was acidic in nature, where as in Bangalore south -Jayanagar was 5.74 which was alkaline in nature in urban area. The VHM pH of Devanahalli was 6.17, Kanakapura 6.26 and Ramanagara area was 6.21 , which were alkaline in nature and free from acid rain in rural area. .The $\mathrm{pH}$ of Bulk precipitation of Bangalore urban area decreases from 6.61 alkaline (1974-1984) to 5.20-5.40 acidic (1996-2005), due to the dominance of acidic species. The decreasing of $\mathrm{pH}$ in the precipitation of the city could be because of $\mathrm{SO}_{4}{ }^{2-}$ and $\mathrm{NO}_{3}{ }^{-}$ions. $\mathrm{NH}_{4}{ }^{+}$and $\mathrm{Ca}^{2+}$ were acting as neutralizing ions or in the absence of these ions; the $\mathrm{pH}$ reduction of bulk precipitation may be much faster towards acidic range. The study established through statistical analysis, that positive correlation coefficient between $\mathrm{H}^{+}$and $\mathrm{SO}_{4}{ }^{2-}$ and $\mathrm{H}^{+}$ and $\mathrm{NO}_{3}{ }^{-}$in the bulk precipitation samples of the urban area indicating lower $\mathrm{pH}$ values were controlled by $\mathrm{H}_{2} \mathrm{SO}_{4}$ and $\mathrm{HNO}_{3}$. Hence the study established that the Bangalore atmosphere is dominated by acidic species throughout the study period. The decreasing trend of $\mathrm{pH}$ in the precipitation in the city may be attributed to local emissions of $\mathrm{SO}_{2}$ and $\mathrm{NOx}$ from urban activities.
\end{abstract}

Keywords: Bulk precipitation, Acid rain, Chemical composition, Neutralizing factors

\section{INTRODUCTION}

Precipitation chemistry is dependent on its acidic and alkaline ions composition and the acidic effect neutralizing capacity on the alkaline species like $\mathrm{Ca}^{2+}, \mathrm{Mg}^{2+}, \mathrm{Na}^{+}$, and $\mathrm{NH}_{4}^{+}$. Precipitation is an efficient pathway for removing the gases and particles from atmosphere. It also plays the significant role in controlling the concentration of these species. The precipitation provides important information from which the deposition to the earth's surface of water soluble gases and aerosols bound constituents can be estimated. Precipitation however has unique scavenging properties, which makes it a useful indicator of ambient pollution levels. Urban /suburban environment attracts more people from rural areas and it is these urban areas that have traditionally been subjected to high concentrations of air pollutants. The effects of acid deposition and its precursors can often be seen in the urban environment.

Recently, acid rain problem has become common in urban areas, because of significant increase in the atmospheric emissions resulting from industries and automobiles. Rural and urban precipitation studies should be conducted using number of sampling stations. Acid precipitation is generally defined as precipitation with $\mathrm{pH}$ less than 5.60 (Likens, 1976). In other words acid rain means the presence of excessive acids in precipitation. Unfortunately, very few data, on precipitation composition are available from the rural sites in India. For this purpose, five sites of different characteristics within Bangalore urban areas (two sites) and three rural sites, as rural background representative have been selected to assess the influence of intensive agricultural practices, to compare the chemical composition of precipitation in different environments. 


\section{MATERIALS AND METHODOLOGY}

The Fig 1, shows the Bangalore urban and rural area sites for sampling of bulk precipitation. Greater Bangalore city is thickly populated and industrialized. It is located at latitude of $12^{0} 58^{1} \mathrm{~N}$ and longitude of $77^{0} 35^{1} \mathrm{E}$ at an altitude of $921 \mathrm{~m}$ MSL. The study area of Bangalore city was divided into two areas: i) residential area with commercial activities and (ii) Industrial area with commercial activities. The residential area selected in Bangalore south (Jayanagar,) and the industrial area selected in Bangalore north, (Hebbal). Number of small, medium and large scale industries exists in and around the city. These industries include; engineering, chemical, pharmaceutical, food, brewery and distillery, textile, steel and metal smelting industries. The other three stations, Devanahalli, Ramanagara and Kanakapura are belongs to rural area with agricultural activities.

In order to investigate the sources of pollutants, the data of chemical species obtained in precipitation were compiled annual wise. Precipitation collection instruments were kept about $6 \mathrm{~m}$ above the ground at sampling stations. Precipitation amounts were determined by bulk sampling on a daily or weekly basis. Bulk sampler is the common name of a collector that is open all the time. It thus collects rain as well as some particulate matter deposited by sedimentation of local soil dust heavily influence the chemical composition of the samples or impaction when air is moving over the opening. It is also open for insects and other material of biogenic origin. The collection efficiency for this kind of "dry deposition" is usually substantially different from that of any surface in nature or in urban areas and can thus not represent real dry deposition.

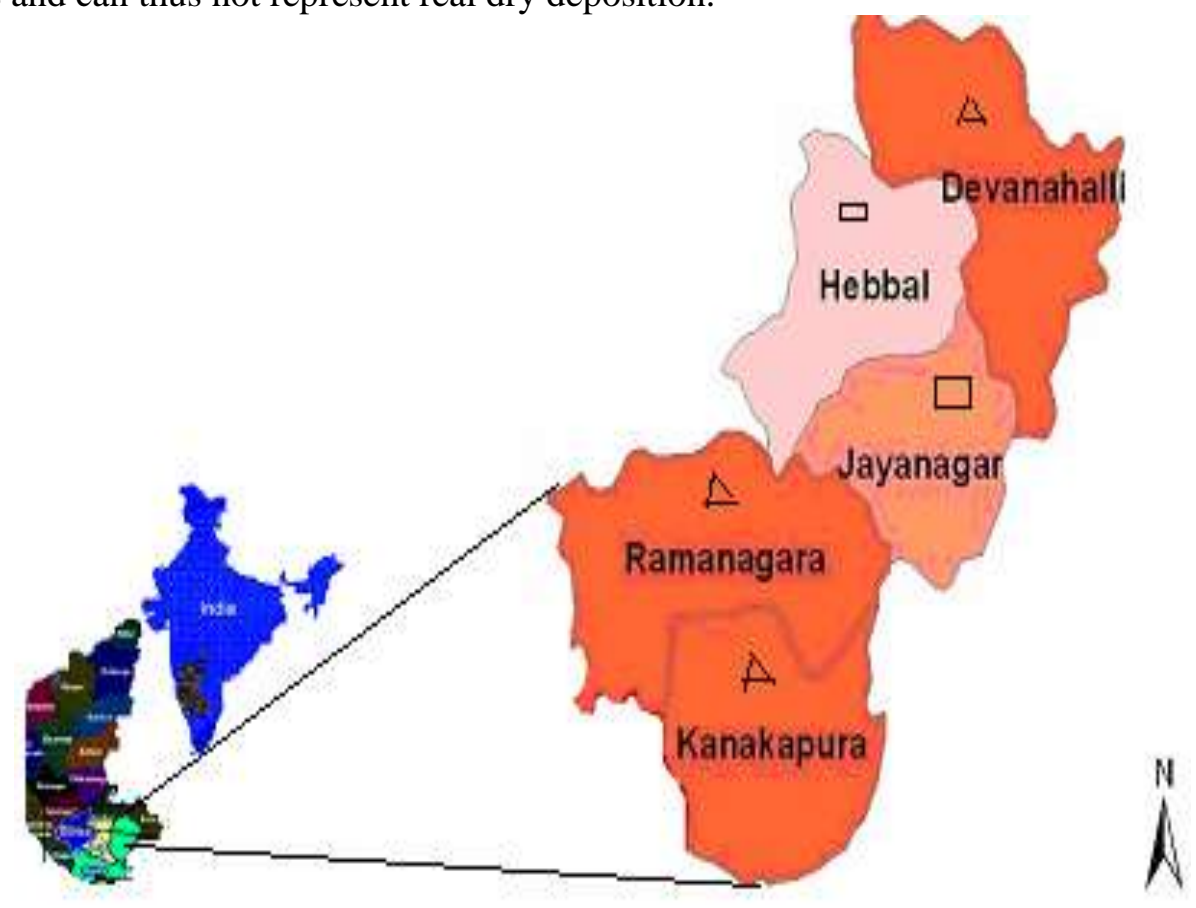

(Note: a uthen site A rual site).

Fig: 1. Bangalore urban and rural area showing the sampling sites.

During the study period, 316 bulk precipitation samples were collected from the five sampling station in Karnataka, during the period of 2005 to 2007. Bulk Precipitation collector used for collection of bulk precipitation (wet and dry) samples in this study and it was designed by Likens (1976) as cited by Ramalingaiah (1985) and Shivashankara et al., (1998). Collector consists of a polyethylene funnel (18cm dia.) connected to 5 liters Polyethylene reservoir. The reservoir was 
attached to a vapors trap and vapors barrier tygon tubing which was provided by a loop to prevent gas exchange between the atmosphere and the samples and evaporation from the reservoir. Samples were transported to the research Laboratory, PESCE, for chemical analysis and kept in a refrigerator at $4^{\circ} \mathrm{C}$ until the completion of all the analysis. The measuring sites were visited daily around $9.00 \mathrm{am}$ (Local Time) and recorded the rainfall. The proper care was taken in collection and preservation of these samples until all the analysis were completes. Samples that were found to be contaminated with dust or bird dropping were removed. The samples collected were analyzed for $\mathrm{pH}$, cations $\left(\mathrm{Ca}^{2+}, \mathrm{Mg}^{2+}, \mathrm{Na}^{+}, \mathrm{K}^{+}\right.$, and $\left.\mathrm{NH}_{4}{ }^{+}-\mathrm{N}\right)$ and anions $\left(\mathrm{Cl}^{-}, \mathrm{SO}_{4}{ }^{2-}, \mathrm{HCO}_{3}{ }^{-}, \mathrm{NO}_{2}^{-} \mathrm{N}, \mathrm{NO}_{3}{ }^{-} \mathrm{N}\right.$ and $\left.\mathrm{PO}_{4}{ }^{3-}-\mathrm{P}\right)$ as per the standard methods(2005).

\section{RESULTS AND DISCUSSION}

\subsection{VARIATIONS OF PH WITH ACIDIC AND ALKALINE SPECIES}

Review of Table 1, volume weighted mean (VWM) pH of 5.74 and 4.70 were observed in Jayanagar (Bangalore South) and Hebbal (Bangalore north) respectively for the year 2005-07. The $\mathrm{pH}$ of the Hebbal was acidic in nature which is less than 5.6, because of rapid urbanization and industrialization. Presence of excessive concentration of sulfate and nitrate, contributes more acidic deposition in the study area, which results in acid rain. This shows the deficiency of the cations. The $\mathrm{pH}$ of the Jayanagar was 5.74, which is slightly alkaline in nature, due to presence of calcium and ammonia ion, which acts as a neutralizing factor. The $\mathrm{pH}$ of Bulk precipitation of Bangalore urban area decreases from 6.61 alkaline (1974-1984) to 5.20-5.40 acidic (1996-2005), due to the dominance of acidic species. The probable reasons for decreasing trend of $\mathrm{pH}$ in the Bangalore city from alkaline rain to acid rain during last two and half decades can be attributed towards the rapid industrialization, urbanization and also rapid increasing automobiles. The VWM pH of Devanahalli was 6.17, Kanakapura 6.26 and Ramanagara area was 6.21 , which were alkaline in nature and free from acid rain where calcium and ammonia are acting as a neutralizing factor.

The ratio of $\left[\mathrm{Ca}^{2+}+\mathrm{NH}_{4}|:| \mathrm{SO}_{4}{ }^{2-}+\mathrm{NO}_{3}{ }^{-}\right] 2.14$ was maximum in Kanakapura rural area followed by 1.76 in Ramanagara, 1.38 in Devanahalli area, 1.29 in Jayanagar urban area and 0.83 in Hebbal area. The higher ratios in precipitation indicate that the acidity generated by $\mathrm{SO}_{4}{ }^{2-}$ and $\mathrm{NO}_{3}{ }^{-}$is neutralized by the alkaline species resulting in alkaline rain or higher $\mathrm{pH}$ values $6.05,6.10,5.90,5.70$ and 4.70 respectively(Table 1). Whereas, lower ratios were determined for Hebbal area (0.37) and this ratio were less than unity, which demonstrate that the acidity generated by $\mathrm{SO}_{4}{ }^{2-}$ and $\mathrm{NO}_{3}{ }^{-}$is not neutralized by (the alkaline species resulting in acid rain $(\mathrm{pH} 4.70)$. The acidic components $\mathrm{SO}_{4}{ }^{2+}$ and $\mathrm{NO}_{3}$ were responsible for decreasing the $\mathrm{pH}$ of bulk precipitation Bangalore urban area particularly Hebbal area.

\subsection{ANNUAL IONIC COMPOSITION OF BULK PRECIPITATION AT URBAN AND RURAL AREA}

The average volume weighted mean (VWM) concentration ( $\mu$ eq $\ell^{-}$) was used for determination of chemical composition of precipitation and represented Fig 1. The composition of Hebbal area, the bulk precipitation for the study period was estimated as: $\mathrm{SO}_{4}{ }^{2-}, 25 \%$; of total major ions followed by $\mathrm{Ca}^{2+}, 20 \%$. The overall concentration of cations and anions is follows a general in descending order as $\mathrm{SO}_{4}{ }^{2-}>\mathrm{Ca}^{2+}>\mathrm{HCO}_{3}{ }^{-}>\mathrm{NO}_{3}{ }^{-}>\mathrm{Na}^{+}>\mathrm{Cl}^{-}>\mathrm{NH}_{4}{ }^{+}>\mathrm{H}^{+}>\mathrm{Mg}^{2+}>\mathrm{K}^{+}>\mathrm{PO}_{4}{ }^{3}>>$ and $\mathrm{NO}_{2}$. The composition of Jayanagar area, was estimated as: $\mathrm{Ca}^{2}, 26 \%$ of total major ions followed by $\mathrm{SO}_{4}{ }^{2-}, 13 \%$. The overall concentration is follows a general in descending order as $\mathrm{Ca}^{2+}>\mathrm{SO}_{4}{ }^{2}>\mathrm{HCO}_{3}>\mathrm{NH}_{4}{ }^{+}>\mathrm{NO}_{3}{ }^{-}$ $>\mathrm{Na}^{+}>\mathrm{Cl}->\mathrm{Mg}^{2+}>\mathrm{K}^{+}>\mathrm{PO}_{4}{ }^{3}>\mathrm{NO}_{2}{ }^{-}>\mathrm{H}^{+}$. The study established that $\mathrm{Ca}^{2+}$ and $\mathrm{SO}_{4}{ }^{2-}$ were dominated ions in Bangalore bulk precipitation.

Whereas, in rural area, the ionic composition of Devanahalli of bulk precipitation indicates that the $\mathrm{Ca}^{2+}$ the most abundant cations. On a chemical equivalent basis, it accounted for $43 \%$ of major ions, followed by $\mathrm{SO}_{4}{ }^{2-} 12 \%$. The overall concentration is follows a general in descending order as

Proceedings of the $15^{\text {th }}$ International Forestry and Environment Symposium, 26-27 November 2010.

Published by Department of Forestry and Environmental Science, University of Sri Jayewardenepura, Sri Lanka. 
$\mathrm{Ca}^{2+}>\mathrm{SO}_{4}{ }^{2-}>\mathrm{NO}_{3}{ }^{-}>\mathrm{HCO}_{3}>\mathrm{NH}_{4}{ }^{+}>\mathrm{Na}^{+}>\mathrm{Cl}^{-}>\mathrm{K}^{+}>\mathrm{Mg}^{2+}>\mathrm{PO}_{4}{ }^{3}>\mathrm{H}^{+}$and $\mathrm{NO}_{2}{ }^{-}$. The Kanakapura of bulk precipitation indicates that the $\mathrm{Ca}^{2+}$ the most abundant cation. On a chemical equivalent basis, it accounted for $32 \%$ of major ions, followed by $\mathrm{HCO}_{3}, 14 \%$. The overall concentration is follows a general in descending order as $\mathrm{Ca}^{2+}>\mathrm{HCO}_{3}{ }^{-}>\mathrm{NH}_{4}{ }^{+}>\mathrm{SO}_{4}{ }^{2-}>\mathrm{Cl}^{-}>\mathrm{NO}_{3}{ }^{-}>\mathrm{Na}^{+}>\mathrm{Mg}^{2+}>\mathrm{K}^{+}>\mathrm{PO}_{4}{ }^{3}>\mathrm{NO}_{2}{ }^{-}$ and $\mathrm{H}^{+}$. The Ramanagara of bulk precipitation indicates that, $\mathrm{Ca}^{2+}$ was major ion and it accounted for $33 \%$ of major ions, followed by followed by $\mathrm{HCO}_{3}, 21 \%$. The overall concentration of cations and anions is follows a general is in descending order as $\mathrm{Ca}^{2+}>\mathrm{HCO}_{3}{ }^{-}>\mathrm{NO}_{3}{ }^{-}>\mathrm{Cl}^{-}>\mathrm{NH}_{4}{ }^{+}>\mathrm{K}^{+}>\mathrm{SO}_{4}{ }^{2-}$ $>\mathrm{Na}^{+}>\mathrm{Mg}^{2+}>\mathrm{PO}_{4}{ }^{3}>\mathrm{NO}_{2}{ }^{-}$and $\mathrm{H}^{+}$. The study indicates that $\mathrm{Ca}^{2+}, \mathrm{SO}_{4}{ }^{2-}$ and $\mathrm{HCO}_{3}$ are dominated in rural major ions in rural bulk precipitation. Based on the analyses of the major ions of bulk precipitation in study area, it can be concluded that the major ion was $\mathrm{Ca}^{2+}$. Several researchers reported that the $\mathrm{Ca}^{2+}$ component may play an important meteorological role in Indian precipitation. Sequeria and Kelkar, (1978) and Khemani, et al, (1989). The possible source of $\mathrm{Ca}^{2+}$ ions in study area may be identified as soil particulate, which are the major sources of aerosols in study area bulk precipitation. Whereas, $\mathrm{HCO}_{3}{ }^{-}$, ions in rural areas possibly reflects the sources of $\mathrm{HCO}_{3}{ }^{-}$in bulk precipitation may be derived from alkaline soil particulates such as $\mathrm{MgCO}_{3}$ and $\mathrm{CaCO}_{3}$.

Table 1: Annual VWM concentrations $\left(\mu \mathrm{eq} \ell^{-1}\right)$ of ions, conductivity, $\mathrm{pH}$, and ratios of acidic and alkaline species in bulk precipitation samples at Bangalore urban and rural area during 2005-07

\begin{tabular}{|c|c|c|c|c|c|}
\hline \multirow{2}{*}{$\begin{array}{l}\text { Parameter } \\
\text { /2005-07 }\end{array}$} & Hebbal & Jayanagar & Devanahalli & Kanakapura & \multirow[t]{2}{*}{ Ramanagara } \\
\hline & \multicolumn{2}{|c|}{ URBAN AREA } & \multicolumn{2}{|c|}{ RURAL AREA } & \\
\hline $\mathbf{N}$ & 64 & 62 & 66 & 62 & 62 \\
\hline EC & 37.10 & 26.60 & 26.70 & 40.90 & 41.80 \\
\hline $\mathbf{H}^{+}$ & 19.87 & 1.80 & 1.20 & 0.45 & 0.35 \\
\hline pH & 4.70 & 5.70 & 5.90 & 6.05 & 6.10 \\
\hline $\mathrm{Ca}^{2+}$ & 93.30 & 96.5 & 101.1 & 89.30 & 79.00 \\
\hline $\mathbf{M g}^{2+}$ & 12.85 & 10.50 & 10.00 & 8.15 & 8.00 \\
\hline $\mathrm{Na}^{+}$ & 37.65 & 38.4 & 38.4 & 21.45 & 22.65 \\
\hline $\mathbf{K}^{+}$ & 11.45 & 10.05 & 11.7 & 6.60 & 5.60 \\
\hline $\mathrm{NH}_{4}-\mathrm{N}$ & 32.35 & 32.95 & 31.3 & 31.75 & 35.30 \\
\hline $\mathrm{Cl}^{-}$ & 36.65 & 40.05 & 35.00 & 23.50 & 26.60 \\
\hline $\mathrm{SO}_{4}{ }^{2-}$ & 109.9 & 50.55 & 47.1 & 25.5 & 24.4 \\
\hline $\mathrm{HCO}_{3}$ & 54.40 & 44.9 & 46.9 & 44.00 & 46.25 \\
\hline $\mathrm{NO}_{3}^{-}-\mathrm{N}$ & 40.60 & 49.85 & 48.5 & 31.05 & 40.45 \\
\hline $\mathrm{NO}_{2}^{-}-\mathrm{N}$ & 5.15 & 4.20 & 4.10 & 1.70 & 3.40 \\
\hline $\mathrm{PO}_{4}{ }^{3}-\mathrm{P}$ & 6.80 & 6.55 & 5.00 & 2.35 & 1.90 \\
\hline$* \mathbf{N} . \mathbf{F}$ & 0.83 & 1.29 & 1.38 & 2.14 & 1.76 \\
\hline \$Ratio & 0.37 & 1.00 & 1.03 & 1.22 & 1.66 \\
\hline
\end{tabular}

$\mathrm{N}=$ No. of samples, $\mathrm{EC}=$ electrical conductivity, $\mu \mathrm{s} / \mathrm{cm}$.

$*$ N.F. $=$ Neutralization factor $=\left[\mathrm{Ca}^{2+}+\mathrm{NH}_{4}^{+}\right]:\left[\mathrm{SO}_{4}{ }^{2-}+\mathrm{NO}_{3}{ }^{-}\right]$

$\$$ Ratio $=\mathrm{NO}_{3}{ }^{-} / \mathrm{SO}_{4}{ }^{2-}$ 


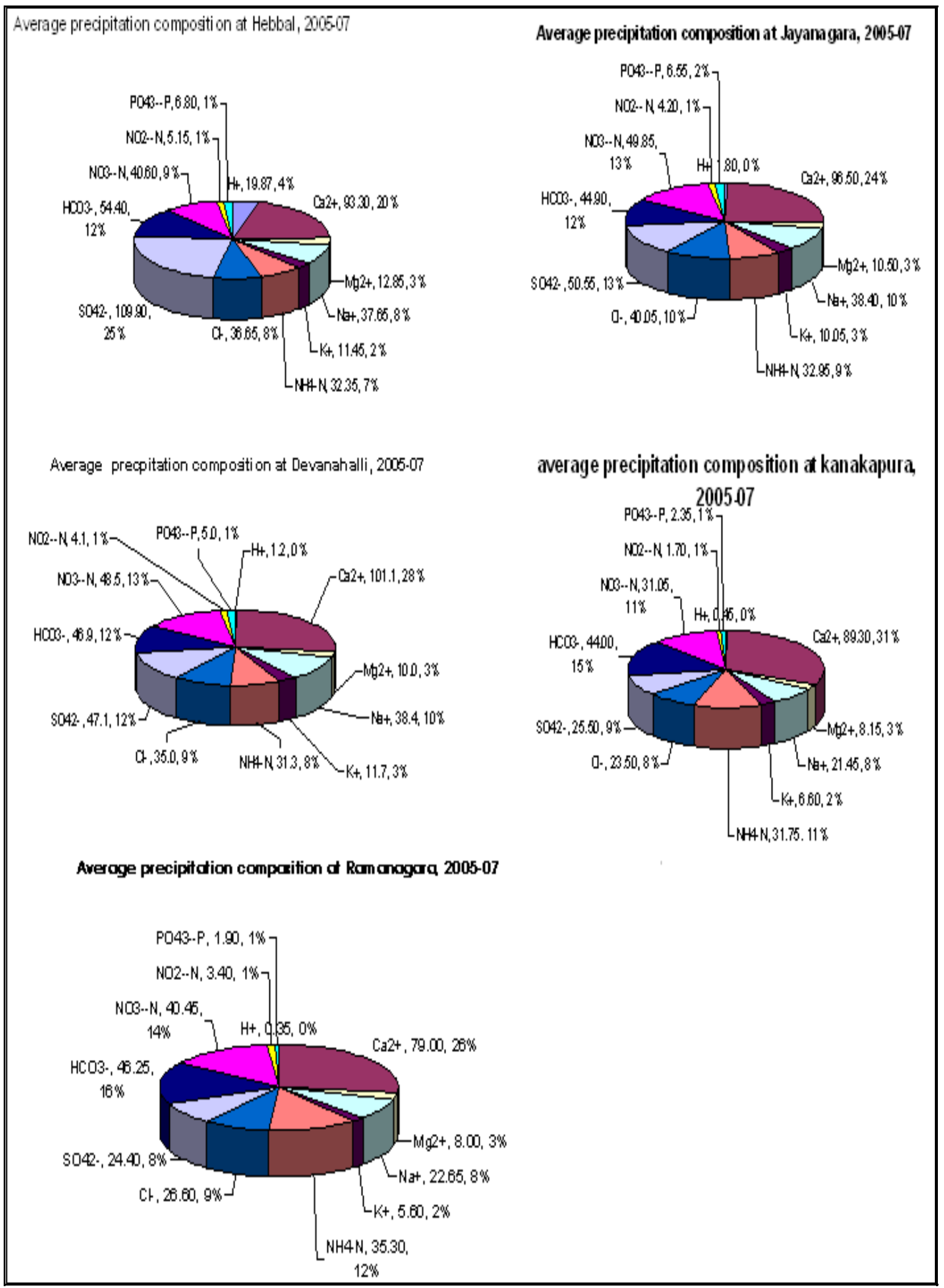

Fig 2. Average chemical composition of bulk precipitation at Bangalore urban and rural areas 
Table 2: Correlation matrix between ions in bulk precipitation in five urban sampling stations.

\begin{tabular}{|c|c|c|c|c|c|}
\hline Area & Hebbal & Jayanagara & Devanahalli & Ramanagara & Kanakapura \\
\hline $\mathrm{H}-\mathrm{SO}_{4}$ & $0.81 * *$ & 0.22 & -0.18 & 0.26 & -0.14 \\
\hline $\mathrm{H}-\mathrm{NO}_{3}$ & $0.70 * *$ & 0.31 & -0.08 & -0.24 & 0.21 \\
\hline $\mathrm{Ca}-\mathrm{Mg}$ & $0.44^{*}$ & 0.23 & 0.30 & 0.05 & 0.30 \\
\hline $\mathrm{Ca}-\mathrm{Na}$ & 0.03 & 0.10 & $0.49 *$ & 0.11 & -0.06 \\
\hline $\mathrm{Ca}-\mathrm{NH}_{4}^{+}$ & $0.47 *$ & $0.61 * *$ & $0.54 * *$ & $0.65 * *$ & $0.50 * *$ \\
\hline $\mathrm{Ca}-\mathrm{SO}_{4}$ & $0.59 * *$ & $0.76^{* *}$ & $0.48 *$ & $0.51 * *$ & $0.73 * *$ \\
\hline $\mathrm{Ca}-\mathrm{NO}_{3}$ & $0.60 * *$ & $0.68 * *$ & $0.51 * *$ & $0.45^{*}$ & 0.11 \\
\hline $\mathrm{Mg}-\mathrm{K}$ & 0.26 & $0.41^{*}$ & 0.05 & $0.50 * *$ & 0.25 \\
\hline $\mathrm{Mg}-\mathrm{NH}_{4}{ }^{+}$ & $0.41 *$ & $0.43^{*}$ & 0.06 & 0.27 & 0.30 \\
\hline $\mathrm{Mg}-\mathrm{SO}_{4}$ & $0.55 * *$ & $0.45 * *$ & $0.58^{* *}$ & $0.62 * *$ & $0.65 * *$ \\
\hline $\mathrm{Mg}-\mathrm{NO}_{3}$ & $0.51 *$ & 0.19 & 0.22 & -0.11 & -0.11 \\
\hline $\mathrm{K}-\mathrm{NH}_{4}^{+}$ & 0.12 & 0.32 & -0.02 & $0.46^{*}$ & $0.48^{*}$ \\
\hline $\mathrm{K}-\mathrm{SO}_{4}{ }^{2}$ & 0.05 & 0.18 & $0.50 * *$ & 0.22 & 0.12 \\
\hline $\mathrm{NH}_{4}^{+}-\mathrm{Cl}$ & 0.35 & 0.14 & $0.44 *$ & 0.26 & $0.57 * *$ \\
\hline $\mathrm{NH}_{4}^{+}-\mathrm{SO}_{4}$ & $0.51 * *$ & $0.62 * *$ & $0.41 *$ & 0.20 & $0.60 * *$ \\
\hline $\mathrm{NH}_{4}^{+}-\mathrm{NO}_{3}$ & $0.41 *$ & $0.47 *$ & $0.64 * *$ & $0.42 *$ & 0.38 \\
\hline Cl- $\mathrm{SO}_{4}$ & 0.32 & 0.03 & 0.19 & 0.12 & $0.40^{*}$ \\
\hline $\mathrm{Cl}-\mathrm{NO}_{3}$ & 0.30 & 0.04 & 0.38 & 0.08 & $0.44 *$ \\
\hline $\mathrm{SO}_{4}^{2}-\mathrm{NO}_{3}$ & $0.77 * *$ & $0.72 * *$ & $0.48 *$ & 0.24 & 0.33 \\
\hline
\end{tabular}

The symbol * 5\% and ** $1 \%$ indicates positive significant correlation coefficient.

The symbol \$ 5\% and \$ \$1\% indicates negative significant correlation coefficient.

Table 3: Factor loading matrix

\begin{tabular}{|c|c|c|c|c|c|c|c|c|c|c|}
\hline \multirow{3}{*}{ Variable } & \multicolumn{4}{|c|}{ Bangalore Urban Area } & \multicolumn{6}{|c|}{ Bangalore Rural Area } \\
\hline & \multicolumn{2}{|c|}{ Hebbal } & \multicolumn{2}{|c|}{ Jayanagar } & \multicolumn{2}{|c|}{ Devanahalli } & \multicolumn{2}{|c|}{ Ramanagara } & \multicolumn{2}{|c|}{ Kanakapuı } \\
\hline & Factor1 & Factor2 & Factor1 & Factor2 & Factor 1 & Factor 2 & Factor 1 & Factor 2 & Factd & Factor 2 \\
\hline $\mathbf{H}^{+}$ & 0.961 & -0.113 & 0.124 & 0.031 & 0.458 & -0.431 & -0.115 & 0.202 & -0.01 & 0.202 \\
\hline $\mathrm{Ca}^{2+}$ & 0.314 & -0.895 & 0.328 & -0.219 & 0.714 & 0.397 & -0.914 & 0.314 & -0.78 & 0.314 \\
\hline $\mathrm{Mg}^{2+}$ & 0.171 & -0.169 & 0.044 & -0.026 & 0.171 & -0.061 & 0.016 & 0.122 & 0.141 & 0.122 \\
\hline $\mathrm{Na}^{+}$ & 0.019 & -0.025 & -0.048 & 0.154 & 0.019 & 0.158 & 0.014 & -0.035 & 0.088 & -0.035 \\
\hline $\mathbf{K}+$ & 0.009 & -0.094 & 0.083 & -0.019 & 0.009 & 0.014 & 0.354 & -0.055 & 0.368 & -0.055 \\
\hline $\mathrm{NH}_{4}{ }^{+}$ & 0.202 & $\begin{array}{l}-0.189 \\
\end{array}$ & 0.17 & $\begin{array}{l}-0.199 \\
\end{array}$ & 0.602 & 0.112 & -0.02 & 0.295 & 0.328 & 0.295 \\
\hline $\mathrm{Cl}^{-}$ & 0.128 & -0.041 & -0.003 & -0.113 & 0.128 & -0.071 & -0.105 & 0.157 & $0.07 \AA$ & 0.157 \\
\hline $\mathrm{SO}_{4}{ }^{2-}$ & 0.818 & -0.31 & 0.386 & -0.143 & 0.547 & -0.374 & 0.678 & 0.295 & 0.254 & 0.595 \\
\hline $\mathrm{NO}_{3}{ }^{-}-\mathrm{N}$ & 0.620 & -0.265 & 0.862 & -0.105 & 0.665 & 0.474 & 0.873 & 0.262 & $0.76=$ & 0.662 \\
\hline Variance & 2.1741 & 1.0569 & 1.063 & 1.0342 & 2.174 & 1.0665 & 1.049 & 1.2573 & 1.094 & 1.257 \\
\hline$\%$ Variance & 0.217 & 0.106 & 0.106 & 0.103 & 0.217 & 0.107 & 0.105 & 0.126 & $0.10^{d}$ & 0.126 \\
\hline $\begin{array}{l}\text { Probable } \\
\text { contribution }\end{array}$ & $\begin{array}{l}\text { Anthrop } \\
\text { ogenic }\end{array}$ & $\begin{array}{l}\text { Non sea } \\
\text { salt }\end{array}$ & $\begin{array}{l}\text { Anthrop } \\
\text { ogenic }\end{array}$ & $\begin{array}{l}\text { Non sea } \\
\text { salt }\end{array}$ & $\begin{array}{l}\text { Soil/agri } \\
\text { actic }\end{array}$ & $\begin{array}{l}\text { Non sea } \\
\text { salt }\end{array}$ & Soil/agri & $\begin{array}{l}\text { Anthro/ } \\
\text { soil }\end{array}$ & $\begin{array}{l}\text { Soil } \\
\text { /bion }\end{array}$ & $\begin{array}{l}\text { Nonsea } \\
\text { salt }\end{array}$ \\
\hline
\end{tabular}




\subsection{STATISTICAL ANALYSIS}

Table 2 presents Correlation matrix between ions in bulk precipitation in five urban and rural sampling stations during 2005-07. In Hebbal and in Jayanagar, it clearly established that highly significant positive correlation coefficient between $\mathrm{H}^{+}$and $\mathrm{SO}_{4}{ }^{2}$ and also positive relationship between $\mathrm{H}^{+}$and $\mathrm{NO}_{3}{ }^{-}$indicate that decreasing trend of $\mathrm{pH}$, could be attributed to $\mathrm{SO}_{4}{ }^{2-}$ and $\mathrm{NO}_{3}{ }^{-}$in bulk precipitation samples. Positive significant correlation coefficient of $\mathrm{Ca}^{2+}$ with $\mathrm{SO}_{4}{ }^{2-}$ and $\mathrm{NH}_{4}{ }^{+}$with $\mathrm{SO}_{4}{ }^{2-}$ which indicates that were acting as neutralizing ions. In other words, in the absence of these ions, $\mathrm{pH}$ reduction of the city's bulk precipitation may be much faster towards acidic range. The possible sources of $\mathrm{NH}_{4}{ }^{+}$in bulk precipitation may be from animal sources, sewage plants and open drains in the urban area. The decrease of $\mathrm{pH}$ appears to be slow since significant ammonia was also present in bulk precipitation of the city. In Devanahalli, Kanakapura and Ramanagara, is clearly established positive correlation coefficient of $\mathrm{Ca}^{2+}$ with $\mathrm{SO}_{4}{ }^{2-}$ and $\mathrm{NH}_{4}{ }^{+}$with $\mathrm{NO}_{3} \& \mathrm{SO}_{4}{ }^{2}$ - which indicates that $\mathrm{NH}_{4}{ }^{+}$and $\mathrm{Ca}^{2+}$ were acting as a neutralizing ions. The possible sources of $\mathrm{NH}_{4}{ }^{+}$in bulk precipitation may be from animal sources, agricultural activities and open drains in rural area.

\subsection{FACTOR ANALYSIS (VARIMAX ROTATED FACTOR-LOADING MATRIX) FOR URBAN AND RURAL AREAS}

In order to identify possible associations between measured species, to explore possible geochemical and other sources of the dissolved compound in the precipitation and in order to obtain a better distribution of the principal components in the matrix of data, factor analysis was performed (Kumar et al, 2002). Based on the observations, only factor loads of higher than 0.5 have been deemed to be stastically significant. Review of Table 3 shows factor loading of bulk precipitation for the sampling station Bangalore north (Hebbal), the first factor with $22 \%$ of the total variation in relation to raw data, showed higher loading for $\mathrm{NO}_{3}{ }^{-}$, characterized the contribution from the industries and automobiles. Whereas, Bangalore South (Jayanagar), the first factor with $11 \%$ of total variation in relation to the raw data, showed higher loading for $\mathrm{Ca}^{2+}, \mathrm{SO}_{4}{ }^{2-}$, and $\mathrm{NO}_{3}^{-}$, characterized the contribution from anthropogenic sources (automobiles). On the other hand, factor loading of bulk precipitation for the sampling rural area of Devanahalli, Kanakpura and Ramanagara, showed higher loading for $\mathrm{Ca}^{2+}, \mathrm{NH}_{4}{ }^{+}$and $\mathrm{NO}_{3}{ }^{-}$(about $10-20 \%$ of total variation) characterized the contribution of $\mathrm{Ca}^{2+}$ from natural source (soil), and $\mathrm{NH}_{4}{ }^{+}-\mathrm{N}$ from human and animal excursion and agricultural activities, and $\mathrm{NO}_{3}{ }^{-}$may be characterized the contribution from biomass burning and agricultural activities.

\section{CONCLUSIONS}

The study showed that the average VWM pH of bulk precipitation at Bangalore urban area was 5.4, which was acidic in nature. Whereas, $\mathrm{pH}$ of Devanahalli rural area was 6.17, Kanakapura 6.26 and Ramanagara area was 6.21, which were alkaline in nature. $\mathrm{pH}$ in bulk precipitation of the Bangalore urban showing a decreasing trend from an alkaline precipitation towards acidic precipitation. The $\mathrm{pH}$ value decreased from an average of 6.61 to 5.40 during last two and half decades. The study established through statistical analysis, that positive correlation coefficient between $\mathrm{H}^{+} \& \mathrm{SO}_{4}{ }^{2-}$ and $\mathrm{H}^{+} \& \mathrm{NO}_{3}{ }^{-}$in the bulk precipitation samples of the city. The decreasing of $\mathrm{pH}$ in the precipitation of the city could be because of $\mathrm{SO}_{4}{ }^{2-}$ and $\mathrm{NO}_{3}{ }^{-}$ions. $\mathrm{NH}_{4}{ }^{+}$and $\mathrm{Ca}^{2+}$ were acting as neutralizing ions or in the absence of these ions; the $\mathrm{pH}$ reduction of bulk precipitation may be much faster towards acidic range. The decreasing trend of $\mathrm{pH}$ in the precipitation in the city may be attributed to local emissions of $\mathrm{SO}_{2}$ and $\mathrm{NO}_{\mathrm{x}}$ from urban activities. The possible source of $\mathrm{Ca}^{2+}$ ions in urban and rural area may identified as soil particulate, which are the major source of aerosols in bulk precipitation. The possible source of $\mathrm{NH}_{4}$ may be from wastewater treatment, open drains and agricultural activities. 


\section{ACKNOWLEDGMENT}

The authors are thankful to field staff for their help in the collection and analysis of precipitation samples. The study was a part of research project work by research centre PES College of Engineering, Mandya-571401, and Karnataka state, INDIA. The authors also thank the Principal and Head of the Department at this Institute, for their co-operation and financial support was provided by VTU, Belgaum, Karnataka, India.,

\section{REFERENCES}

Khemani, L.T., Momin, G.A., Prakash Rao, P.S,, Safai, P.D., Singh, G., Chatterhee, R.N., Prakash, P., 1989. Long term effects of pollutants Ion $\mathrm{pH}$ of rain water in North India. Atmospheric Environment 23, 753-756.

Khemani, L.T., Momin, G.A., Rao, P.S.P., Safai, P.D.,(1989). Spread of Acid Rain over India.Atmos. Environ. 23: 757-762.

Kumar, R.A., Rani, Singh, S.P., Kumari, K.M. and Srivastava, S.S. (2002). A Long-Term Study on Chemical Composition of Rainwater at Dayalbagh, a Suburban Site of Semiarid Region, J. of Atmos. Chem. 41: 265-279

Likens, G.E., et alJ.,(1979) Acid rain scientific American 214:4 pp 45-51.

Momin.. G.A. et al. (2005). Study of Chemical Composition of Rainwater at an Urban (Pune) and a Rural (Sinhagad) Location in India, J. of Geophysical Res. vol. D08302.

Naik, M.S., Momin, G.A.,Pillai A.G. Rao, P.S.P. Khemani, L.T.,, 1995.”Precipitation chemistry at Sinhgad - a hill station in India., Water, Air and soil pollution,85,pp-21 61-2166.

Ramalingaiah, (1985): Monitoring of water quality changes between the protected chain lakes and unprotected chocolate lake. Ph.D thesis submitted to Technical University of Navascotia, Halifax, Canada.

Safai, P.D., Rao, P.S.P., Momin, G.A., Ali, K., Chate, D.M. and Praveen, Chemical Composition of Precipitation during 1984-2002 at Pune, India. Atmos. Environ. 38: 1705-714

Satsangi, G.S., Lakhani, A., Khare, P., Singh, S.P., Kumari, K.M.(1998). Composition of Rainwater at Semiarid Rural Site in India. Atmos. Environ. 32: 3783-3793.

Singh, S.P. et al., (2006) Chemical characterization of dew at a regional representative site of NorthCentral India,Dayalbagh Educational Institute, 2006.

Sequeira, R., Kelkar, D., (1978). Geochemical implications of summer monsoonal rain water composition over India. Journal of Applied Meteorology 17, 1390-1396.

Shivashankara, G.P , Ranga, K., and Manamohanrao (1998) : Chemical composition and spatial variation of bulk precipitation in Bangalore, $\mathrm{PhD}$ thesis submitted to Bangalore university, Bangalore.

Standard Methods, for examination of water and waste, $19^{\text {th }}$ edition, APHA, AWWA and WPCF (2005), New York.

Varna, G.S.(1989): Background trends of pH of precipitation over India. Atmospheric Environment, v 23, No.4, pp. 747-751 